\title{
Phytochemical screening and determination of minerals and heavy metals in the flowers of Nyctanthes arbor-tristis $\mathbf{L}$.
}

\author{
M. M. Haque ${ }^{1,2 *}$, N. Sultana ${ }^{1}$, S. M. T. Abedin ${ }^{2}$ and S. E. Kabir ${ }^{2}$ \\ ${ }^{1}$ Bangladesh Council of Scientific and Industrial Research (BCSIR), Dhaka, Bangladesh \\ ${ }^{2}$ Department of Chemistry, Jahangirnagar University, Savar, Dhaka-1342, Bangladesh
}

Received: 28 January 2019

Revised: 06 March 2019

Accepted: 06 May 2019

DOI: https://doi.org/10.3329/bjsir.v54i4.44566

\begin{abstract}
Dried powder of the flowers of Nyctanthes arbor-tristis L. was analyzed for phytochemical screening, proximate compositions, mineral constituents and heavy metals analysis. The phytochemical screening indicated the presence of carbohydrates, flavonoids, glycosides, cardiac glycosides, reducing sugar, saponins, steroids, tannins and terpenoids. Alkaloids, anthraquinones and phlobatannins were absent. The proximate compositions was found to be high in moisture content $(92.27 \pm 0.09 \%)$, the ash content was found to be $(0.53 \pm 0.02 \%)$ while the protein content was 0.97 $\pm 0.05 \%$ by fresh weight basis. The air dried flowers sample revealed highest in oxygen content $(50.16 \%)$ and lowest in sulfur content $(0.10 \%)$. A total of six anions were analyzed. The sample was found rich in fluoride $(94.87 \pm 2.501 \mathrm{mg} / \mathrm{Kg})$ and sulfate $(165.24 \pm 5.14 \mathrm{mg} / \mathrm{Kg})$ content. A total of fifteen metals were analyzed. Heavy metals such as $\mathrm{Pb}, \mathrm{Cd}, \mathrm{Hg}, \mathrm{Cr}$ and $\mathrm{As}$ were found in trace amounts, which were within the acceptable limits according to WHO and FAO.
\end{abstract}

Keywords: Nyctanthes arbor-tristis L.; Phytochemical screening; Minerals; Heavy metals; Proximate composition

\section{Introduction}

The use of plant and plant products as a therapeutic agent is as old as human civilization. From the ancient time different plant species were used as herbal medicine for various diseases (Annan et al., 2010). In the present days, the interest in the use of medicinal plants has been increased because of their less toxicity especially when compared with synthetic drugs. Today, natural products are responsible for about half of the approved drugs that are currently available (Vlietinck and Apers, 2001). The World Health organization (WHO) also supports the use of medicinal plants (WHO, 2005) for therapeutic use. Thus, medicinal plants are far more intriguing in the field of drug discovery. The medicinal values of different plants lie in its bioactive chemical constituents that create a definite physiological action in human body (Edeoga et al., 2005). The most important bioactive chemical constituents are alkaloids, tannins, flavonoids, steroids, terpenoids, carbohydrates and phenolic compounds (Hill, 1952; Pascaline et al., 2011). Many medicinal plants have been consumed for medicinal purposes as well as for food (Jacob and Shenbagaraman, 2011). The mineral contents of medicinal plants play a vital role in human health (Annan et al., 2010). Moreover excess consumption of minerals higher than their estimated safe daily intake, may create toxicity in human body (Annan et al., 2013). Hazardous toxic metals such as $\mathrm{As}, \mathrm{Al}, \mathrm{Pb}, \mathrm{Cd}, \mathrm{Cr}$, and $\mathrm{Hg}$ can be present in medicinal plants (Yap et al., 2010). In recent days, people have more awareness about the risks associated with the presence of hazardous metals in medicinal plants and their implications (Chong et al., 2007).

Bangladesh is a good land source of medicinal plants. Nyctanthes arbor-tristis L. (Bengali: Sheuli phul, Shefali phul) is an important medicinal plant, which belongs to the genus Nyctanthes and the family Oleaceae. This plant normally grows in tropical and subtropical regions of the country (Rani et al., 2012). Herbal industries are using this plant is for their herbal preparations and formulations. The present study was designed to evaluate the phytochemical 
constituents and the concentration of selected heavy metals and minerals in the flowers of the mentioned plant (Jain and Pandey, 2016; Anuradha et al., 2017). The preliminary study revealed interesting findings which will draw attention to the need for further investigation of the active ingredients identified in the reported species.

\section{Materials and methods}

\section{Collection and Identification of plant materials}

The flowers of Nyctanthes arbor-tristis L. were collected from BCSIR campus, Dhaka, Bangladesh. The plant (specimen \# DACB 38734) was identified from Bangladesh National Herbarium (BNH), Dhaka by their Taxonomist. The collected flowers were air dried at $25-30{ }^{\circ} \mathrm{C}$ in the absence of sunlight. The dried flowers were powdered by a grinder machine. Then they were weighed and stored in an air tight container in dark until use.

\section{Phytochemical screening}

Specific chemical tests were carried out for specific phytochemical constituents. Standard procedures were followed to identify the constituents as described by Sofowara (1993), Trease and Evance (1996), Harborne (1998), Ghani (2003), Mukharjee (2002).

\section{Determination of proximate composition}

The moisture, ash and crude protein contents were determined using the standard methods of the Association of Official Analytical Chemists (AOAC, 1990). The average weight of flowers was determined by weighing fresh flowers under ambient condition. For the determination of Loss on air drying, the fresh flowers were kept in room temperature for 4 to 5 days in absence of sunlight. The average weight loss was calculated by difference. The moisture content was determined by heating the fresh flower samples in a temperature controlled electric oven at $105^{\circ} \mathrm{C}$ until constant weight was achieved (ca. 6 to 10 hours). The moisture content was calculated in percentage $(\mathrm{m} / \mathrm{m})$. For determination of ash content, previously weighed fresh flower sample was taken. Then the sample was made moisture free and the moisture free sample was incinerated at $600{ }^{\circ} \mathrm{C}$ about 6-12 hours in a temperature controlled muffle furnace until ash becomes almost white or grayish white in color. Crude protein was calculated by using following formula.

Protein content $(\%)=$ nitrogen content $(\%) \times 6.25$

\section{CHNS/O analysis}

Powdered flowers samples were analyzed for elements such as carbon, hydrogen, nitrogen, sulfur and oxygen by using a
CHNS/O Elemental Analyzer (Vario Micro Cube, Elementar, Germany). The results for carbon, hydrogen, nitrogen, sulfur content percentage were calculated directly and the percentage of oxygen was calculated indirectly by using the following formula:

Oxygen content $(\%)=100$ - (the sum of carbon, hydrogen, nitrogen, sulfur content percentage)

\section{Determination of anion content}

The sequential determination of fluoride, chloride, nitrite, bromide, nitrate, phosphate and sulfate ions were performed by chemically suppressed ion chromatography.

An aliquot of sample solution was injected into an ion chromatography instrument. The sample was pumped through two columns and a suppressor device into a conductivity detector. The analytical column and the guard column were packed with low-capacity anion exchanger. Ions are separated based on their affinity for the exchange sites of the resin. Anions are identified based on their retention times compared to known standards. Quantization was accomplished by measuring the peak height or area and comparing it to a calibration curve generated from known standards.

\section{Determination of metal composition}

The analysis of minerals and metal compositions were carried out on the sample using the standard methods of the Association of Official Analytical Chemists (AOAC, 1990).

\section{Instrumentation}

$\mathrm{K}$ and Na were analyzed by a Flame Photometer (JENWAY, PFP 7, UK). Mn, Fe, $\mathrm{Zn}, \mathrm{Cu}, \mathrm{Mg}, \mathrm{Ca}$, As and $\mathrm{Hg}$ were analyzed by using Varian AA -240 FS, Australia, while Pb, $\mathrm{Cd}, \mathrm{Cr}$, Ni, and Co were analyzed by a Varian Spectra AA $240 \mathrm{Z}$, Australia, AAS instruments.

\section{Preparation of sample}

The dried powdered sample was used for metal analysis. For analysis of $\mathrm{Mn}, \mathrm{Pb}, \mathrm{Zn}, \mathrm{Cd}, \mathrm{Fe}, \mathrm{Ca}, \mathrm{Cu}, \mathrm{Co}, \mathrm{Cr}, \mathrm{As}, \mathrm{Na}, \mathrm{K}$, $\mathrm{Mg}$ and $\mathrm{Ni}$ the plant samples were incinerated at $550{ }^{\circ} \mathrm{C}$. About $0.1-1.0 \mathrm{~g}$ ash of the sample was dissolved in $5 \mathrm{~mL}$ of 1 $\mathrm{M}$ nitric acid $\left(\mathrm{HNO}_{3}\right)$ by warming on a hot plate for 2-3 minutes. The solution was taken in a $50 \mathrm{~mL}$ volumetric flask and 2 additional portions of $1 \mathrm{M} \mathrm{HNO}_{3}$ were added and diluted to $50 \mathrm{~mL}$ with $1 \mathrm{M} \mathrm{HNO}_{3}$. The solution was filtered through $0.45 \mu$ filter paper. The filtrate was used for further metal analysis. For analysis of Mercury $(\mathrm{Hg})$, the moisture free powdered sample was heated for 30 min with $20 \mathrm{~mL}$ conc. nitric acid. The solution was allowed to cool at room 
temperature and $10 \mathrm{~mL}$ perchloric acid was added to it. The solution was heated on a hot plate until the reaction with $\mathrm{HClO}_{4}$ had completed (after completion of reaction the solution was colorless or yellow). Finally the solution was cooled and filtered in a $50 \mathrm{~mL}$ volumetric flask and the volume was made up to $50 \mathrm{~mL}$ with de-ionized water. A blank sample was also prepared without adding plant sample.

\section{Standards}

NIST traceable standards were used for individual metal analysis. The standards were collected from Scharlau, Sentmenat, Spain and the concentration of each individual stock standard for testing elements was $1000 \mathrm{mg} / \mathrm{L}$. Working standards were prepared by necessary dilutions.

\section{Calibration procedure}

Independent calibration curve was constructed for individual elements from particular working standards. Element concentration in sample was determined from the calibration curve.

\section{Results and discussion}

\section{Phytochemical screening}

The phytochemical screening for the flowers of Nyctanthes arbor-tristis L. showed (Table I) the presence of carbohydrates, flavonoids, glycosides, cardiac glycosides, reducing sugar, saponins, steroids, tannins and terpenoids.

Table I. Phytochemical screening on the flower of Nyctanthes arbor-tristis $\mathrm{L}$.

\begin{tabular}{lll}
\hline Serial no. & Phytochemicals & Test results \\
\hline 1 & Alkaloids & Negative \\
2 & Carbohydrates & Positive \\
3 & Reducing sugars & Positive \\
4 & Anthraquinones & Negative \\
5 & Glycosides & Positive \\
6 & Anthraquinone glycosides & Negative \\
7 & Cardiac glycosides & Positive \\
8 & Saponins & Positive \\
9 & Flavonoids & Positive \\
10 & Steroids & Positive \\
11 & Tannins & Positive \\
12 & Condensed tannins or phlobatanins & Negative \\
13 & Terpenoid & Positive \\
\hline
\end{tabular}

The therapeutic ingredients of plant and animal origins have been used from ancient times by a simple process without the isolation of pure compounds (i.e. in the form of crude drugs or the galenicals prepared from those). About $80 \%$ of the world's population use medicinal plants for treatment of different diseases (WHO, 2005). Phytochemicals are secondary metabolites of a plant which are formed by normal metabolic processes of plant. The medicinal value of a plant lies in these phytochemicals that have a definite physiological action on human body.

Terpenoids are chemically reactive compounds. The presence of terpenoids in medicinal plants was previously reported (Rahila et al., 1994). They are important due to their relationship with essential compounds such as vitamin $\mathrm{A}$ and could be of immense medical applications (Ladipo et al., 2011). Flavonoids are the key groups of secondary metabolites and bioactive compounds in plants. Flavonoids have been demonstrated to have antibacterial, anti-inflammatory, anti-allergic, antiviral and anti-aging activity (Alan and Miller, 1996; Vasantha et al., 2012). Flavonoids are also free radical scavengers that prevent oxidative cell damage, and have strong anticancer activities (Pourmorad et al., 2006; Ugwu et al., 2013). Medicinal plants containing tannins are used for the treatment of intestinal disorders such as diarrhoea and dysentery (Bajai, 2001). Carbohydrates are essential for both plants and animals (Ebun-Oluwa and Alade, 2007). Along with protein and fat, carbohydrates are one of the main energy sources in food (Usunobun et al., 2015). An important class of phytoconstituents known as cardiac glycosides have an important role in medicine because of their actions on heart and used in cardiac insufficiency (Balch and Balch, 2000). It's actions helps in the treatment of congestive heart failure (Yukari et al., 1995). Moreover, glycosides, flavonoids and tannins have hypoglycemic activities (Dhar et al., 1987). Saponins are active constituents with a marked hormonal activity, strong expectorant and aid in the absorption of nutrients (Osabor et al., 2015). They have properties of precipitating and coagulating red blood cells, binding cholesterol, formation of foams in aqueous solutions and hemolytic activity (Abidemi, 2013). Steroids fulfill important roles at different stages of mammalian development comprising prenatal development, growth, reproduction, sexual and social behavior (Adam et al., 2002). Steroids have been reported to have antibacterial properties (Raquel et al., 2007). Some plant steroids reduce the amount of cholesterol in the mammal bloodstream (Wisegeek, 2013). The present phytochemical screening indicated the presence of carbohydrates, flavonoids, glycosides, cardiac glycosides, reducing sugar, saponins, steroids, tannins and terpenoids. The present study also revealed that alkaloids, anthraquinones and phlobatannins were absent (Table I). 


\section{Proximate composition}

The proximate composition obtained for the flower of Nyctanthes arbor-tristis L. are presented in Table II. There were found to the high moisture content $(92.27 \pm 0.09 \%)$, fresh weight basis. The moisture content gives an indication of water soluble vitamins present in the sample (Adinortey et al., 2012). The ash content was found to contain $(0.53 \pm$ $0.02 \%$ ), fresh weight basis. The ash content gives an indication to the rich source of inorganic minerals element that may be present in the sample (Adinortey et al., 2012). The protein content was found to contain $0.97 \pm 0.05 \%$ (fresh weight basis). The proximate composition also included lipid analysis in addition to the ash, moisture, and protein content that provides a general overview of the nutritional value of the plant flower (Kirk, 1993). The data of proximate composition for the flower of Nyctanthes arbor-tristis L. has been reported for the first time. This study shows that Nyctanthes arbor-tristis L. flowers are rich in phytochemicals and that their usage should be strongly recommended for good health.

Table II. Proximate composition for the flower of Nyctanthes arbor-tristis L.

\begin{tabular}{lll}
\hline $\begin{array}{l}\text { Sl. } \\
\text { No. }\end{array}$ & Test parameters & $\begin{array}{l}\text { Result (fresh } \\
\text { weight basis) }\end{array}$ \\
\hline 1 & Average weight of each flower $(\mathrm{g})$ & $0.14 \pm 0.03(\mathrm{n}=98)$ \\
2 & Loss on air drying $(\%)$ & $91.51 \pm 0.06(\mathrm{n}=3)$ \\
3 & Moisture $(\%)$ & $92.27 \pm 0.09(\mathrm{n}=3)$ \\
4 & Ash content $(\%)$ & $0.53 \pm 0.02(\mathrm{n}=3)$ \\
5 & Protein $(\%)$ & $0.97 \pm 0.05(\mathrm{n}=3)$ \\
\hline
\end{tabular}

Data are expressed as Mean $\pm \mathrm{SD}$

\section{CHNS/O composition}

The results for $\mathrm{CHNS} / \mathrm{O}$ composition in the flower of Nyctanthes arbor-tristis L. are presented in Table III. Air dried powdered sample were used for this analysis, and five elements such as nitrogen $(\mathrm{N})$, carbon $(\mathrm{C})$, hydrogen $(\mathrm{H})$, sulfur $(\mathrm{S})$ and oxygen $(\mathrm{O})$ were analyzed. The oxygen content $(50.16 \%)$ was found to be highest in quantity and the sulfur content $(0.10 \%)$ was found to be the lowest among the five elements. These elements play the principle role in formation of chemical constituents of medicinal plants. So quantification of these elements is most essential for physiological and pharmaceutical aspects. In biological system these minerals play significant role for activation of metabolic processes (Shute, 1964).
Table III. CHNS/O composition in the flower of Nyctanthes arbor-tristis $\mathbf{L}$.

\begin{tabular}{lll}
\hline $\begin{array}{l}\text { Sl. } \\
\text { No. }\end{array}$ & Test parameters & $\begin{array}{l}\text { Percent }(\%) \\
\text { composition }\end{array}$ \\
\hline 1 & Nitrogen $(\mathrm{N})$ & 1.82 \\
2 & Carbon $(\mathrm{C})$ & 41.32 \\
3 & Hydrogen $(\mathrm{H})$ & 6.60 \\
4 & Sulfur $(\mathrm{S})$ & 0.10 \\
5 & Oxygen $(\mathrm{O})$ & 50.16 \\
\hline
\end{tabular}

\section{Anion content}

A total of six anions were analyzed in the flowers of Nyctanthes arbor-tristis L.. The obtained results are presented in Table IV. The concentrations of the anions were calculated on fresh weight basis. The concentrations of anions like fluoride $\left(\mathrm{F}^{-}\right)$, chloride $\left(\mathrm{Cl}^{-}\right)$, bromide $\left(\mathrm{Br}^{-}\right)$, nitrate $\left(\mathrm{NO}_{3}{ }^{-}\right)$, nitrite $\left(\mathrm{NO}_{2}^{-}\right)$and sulfate $\left(\mathrm{SO}_{4}{ }^{2-}\right)$ were found to be $94.87 \pm 2.501 \mathrm{mg} / \mathrm{Kg}, 65.75 \pm 1.83 \mathrm{mg} / \mathrm{Kg}, \quad<\mathrm{DL}, 27.44 \pm$ $1.58 \mathrm{mg} / \mathrm{Kg}, \quad<\mathrm{DL}, 165.24 \pm 5.14 \mathrm{mg} / \mathrm{Kg}$, respectively.

Table IV. Anions content in the flower of Nyctanthes arbor-tristis $\mathbf{L}$.

\begin{tabular}{lll}
\hline $\begin{array}{l}\text { S1. } \\
\text { No. }\end{array}$ & Anions & $\begin{array}{l}\text { Concentrations }(\mathrm{mg} / \mathrm{kg}) \\
\text { (fresh weight basis) }\end{array}$ \\
\hline 1 & Fluoride $\left(\mathrm{F}^{-}\right)$ & $94.87 \pm 2.50$ \\
2 & Chloride $\left(\mathrm{Cl}^{-}\right)$ & $65.75 \pm 1.83$ \\
3 & Bromide $\left(\mathrm{Br}^{-}\right)$ & Less than detection limit \\
4 & Nitrate $\left(\mathrm{NO}_{3}^{-}\right)$ & $27.44 \pm 1.58$ \\
5 & Nitrite $\left(\mathrm{NO}_{2}^{-}\right)$ & Less than detection limit \\
6 & Sulfate $\left(\mathrm{SO}_{4}{ }^{2-}\right)$ & $165.24 \pm 5.14$ \\
\hline
\end{tabular}

Data are expressed as mean \pm SD $(n=3)$

Chloride $\left(\mathrm{Cl}^{-}\right)$ion is important in the $\mathrm{pH}$ balance of blood and body, and in the formation of hydrochloric acid in the stomach. It is found in intracellular and extracellular fluids. It is present mainly as $\mathrm{Cl}^{-}$, although plants do contain compounds with covalently bound Cl (Engvild, 1986).

Nitrate and nitrite are naturally occurring anions that are part of the nitrogen cycle. The nitrate ion $\left(\mathrm{NO}_{3}{ }^{-}\right)$is the stable form of combined nitrogen for oxygenated systems. Plants have a high demand for nitrogen and developing meristematic tissues provide a very strong sink for the metabolically controlled process of $\mathrm{NO}_{3}^{-}$absorption by roots (Rao and 
Rains, 1976). Several vegetables and fruits contain 200-2500 $\mathrm{mg} / \mathrm{kg}$ of nitrate (Duijvenboden and Matthijsen, 1989). The nitrite ion $\left(\mathrm{NO}_{2}^{-}\right)$contains nitrogen in a relatively unstable oxidation state. Chemical and biological processes can further reduce nitrite to various compounds or oxidize it to nitrate (ICAIR Life Systems, 1987). Especially nitrate $\left(\mathrm{NO}_{3}\right.$ ${ }^{-}$) has received considerable attention in recent years and is quickly gaining attraction as a health and performance enhancing nutritional supplement. Nitrate $\left(\mathrm{NO}_{3}^{-}\right)$rich plants has also recently gained popularity for proposed anti-cancer and anti-inflammatory properties, and for reduced risk for adverse cardiovascular conditions including stroke, myocardial infarction, systemic and pulmonary hypertension, as well as the formation of gastric ulcers (Detopoulou et al., 2008; Lundberg et al., 2008). It has also been reported that dietary $\mathrm{NO}_{3}^{-}$, administered, enhances exercise tolerance (Bailey et al., 2010; Larsen et al., 2011), reduces blood pressure (BP) and lowers the oxygen $\left(\mathrm{O}_{2}\right)$ cost of cardiovascular exercise (Lansley et al., 2011). It is reported that the inorganic cations $\left(\mathrm{K}^{+}, \mathrm{Ca}^{2+}, \mathrm{Mg}^{2+}\right.$, and $\left.\mathrm{Na}^{+}\right)$ were found to be largely balanced by the organic acid anions together with $\mathrm{NO}_{3}^{-}, \mathrm{H}_{2} \mathrm{PO}_{4}^{-}, \mathrm{Cl}^{-}$, and $\mathrm{SO}_{4}^{2-}$ in the plants (Kirkby, 1974; Lorenz, 1976).

\section{Heavy metals and minerals compositions}

The heavy metals and minerals content in the flower of Nyctanthes arbor-tristis L. were determined by Flame Photometer and Atomic Absorption Spectrometer (Flame, Graphite Furnace and Hydride Generation AAS). A total of fifteen elements designated as essential elements and toxic elements were analyzed. The obtained results are presented in Table V and VI. The concentrations of the elements were calculated on fresh weight basis.

Table V. Essential elements composition in the flower of Nyctanthes arbor-tristis L.

\begin{tabular}{llcc}
\hline $\begin{array}{c}\text { Serial } \\
\text { no. }\end{array}$ & Essential elements & Unit & $\begin{array}{c}\text { Results (fresh } \\
\text { weight basis) }\end{array}$ \\
\hline 1 & Potassium $(\mathrm{K})$ & $\mathrm{mg} / \mathrm{kg}$ & $1841.32 \pm 6.26$ \\
2 & Sodium $(\mathrm{Na})$ & $\mathrm{mg} / \mathrm{kg}$ & $85.74 \pm 2.26$ \\
3 & Calcium $(\mathrm{Ca})$ & $\mathrm{mg} / \mathrm{kg}$ & $207.60 \pm 1.05$ \\
4 & Magnesium $(\mathrm{Mg})$ & $\mathrm{mg} / \mathrm{kg}$ & $138.95 \pm 0.64$ \\
5 & Iron $(\mathrm{Fe})$ & $\mathrm{mg} / \mathrm{kg}$ & $20.73 \pm 1.34$ \\
6 & Copper $(\mathrm{Cu})$ & $\mathrm{mg} / \mathrm{kg}$ & $0.97 \pm 0.01$ \\
7 & Nickel $(\mathrm{Ni})$ & $\mathrm{mg} / \mathrm{kg}$ & $0.04 \pm 0.001$ \\
8 & Cobalt $(\mathrm{Co})$ & $\mathrm{mg} / \mathrm{kg}$ & Less than detection limit \\
9 & Zinc $(\mathrm{Zn})$ & $\mathrm{mg} / \mathrm{kg}$ & $2.23 \pm 0.34$ \\
10 & Manganese $(\mathrm{Mn})$ & $\mathrm{mg} / \mathrm{kg}$ & $0.63 \pm 0.20$ \\
\hline
\end{tabular}

Data are expressed as Mean \pm SD $(n=3)$
Table VI. Toxic elements content in the flowers of Nyctanthes arbor-tristis $\mathbf{L}$.

\begin{tabular}{llcc}
\hline $\begin{array}{c}\text { Serial } \\
\text { no. }\end{array}$ & $\begin{array}{c}\text { Toxic } \\
\text { elements }\end{array}$ & $\begin{array}{c}\text { Concentrations } \\
(\mathrm{mg} / \mathrm{kg})(\text { fresh } \\
\text { weight basis })\end{array}$ & $\begin{array}{c}\text { Maximum recommended } \\
\text { level }(\mathrm{mg} / \mathrm{kg}) \text { according } \\
\text { to WHO and FAO }\end{array}$ \\
\hline 1 & Lead $(\mathrm{Pb})$ & $0.16 \pm 0.002$ & 10 \\
2 & Mercury $(\mathrm{Hg})$ & $0.02 \pm 0.001$ & 0.5 \\
3 & Chromium (Cr) & $0.05 \pm 0.002$ & 2.3 \\
4 & Arsenic (As) & Less than detection limit & 5.0 \\
5 & Cadmium (Cd) & $0.002 \pm 0.001$ & 0.3 \\
\hline
\end{tabular}

Data are expressed as mean $\pm \mathrm{SD}(\mathrm{n}=3)$

The concentrations of essential minerals such as $\mathrm{K}, \mathrm{Na}, \mathrm{Ca}$, $\mathrm{Mg}, \mathrm{Fe}, \mathrm{Zn}, \mathrm{Cu}, \mathrm{Ni}, \mathrm{Co}$ and $\mathrm{Mn}$ were found $1841.32 \pm .6 .26$ $\mathrm{mg} / \mathrm{kg}, 85.74 \pm 2.26 \mathrm{mg} / \mathrm{kg}, 207.60 \pm 1.05 \mathrm{mg} / \mathrm{kg}, 138.95 \pm$ $0.64 \mathrm{mg} / \mathrm{kg}, 20.73 \pm 1.34 \mathrm{mg} / \mathrm{kg}, 2.23 \pm 0.34 \mathrm{mg} / \mathrm{kg}, 0.97 \pm$ $0.01 \mathrm{mg} / \mathrm{kg}, 0.04 \pm 0.001 \mathrm{mg} / \mathrm{kg}, \quad<\mathrm{DL}$ and $0.63 \pm 0.20$ $\mathrm{mg} / \mathrm{kg}$, respectively in the flowers of Nyctanthes arbor-tristis $\mathrm{L}$.

The toxic elements like $\mathrm{Pb}, \mathrm{Hg}, \mathrm{Cr}$, As and $\mathrm{Cd}$ were found $0.16 \pm 0.002 \mathrm{mg} / \mathrm{kg}, 0.02 \pm 0.001 \mathrm{mg} / \mathrm{kg}, 0.05 \pm 0.002 \mathrm{mg} / \mathrm{kg}$, $<\mathrm{DL}$ and $0.002 \pm 0.001 \mathrm{mg} / \mathrm{kg}$, respectively. Those values are within acceptable limits according to WHO (WHO, 2005) and FAO (Codex Alimentarius Commission, 2001).

The minerals, especially $\mathrm{Ca}, \mathrm{Mg}, \mathrm{Fe}, \mathrm{Zn}, \mathrm{Na}$ and $\mathrm{K}$ play a significant role in human metabolism and life process. Calcium $(\mathrm{Ca})$ is an important element because of its role in formations of bones, teeth, heart functions and muscle system (Brody, 1994). Magnesium (Mg) improves insulin sensitivity, protects against diabetes complications (Iwaoka et al., 2011; Saracoglu et al., 2009), reduces blood pressure and also plays a significant role in traumatic brain injury (Cerenak and Vink, 1999). Iron (Fe) is an essential mineral to prevent anemia and cough associated with angiotensin converting enzyme (ACE) inhibitors (Malik et al., 2010; Archana et al., 2011). Zinc (Zn) is necessary for growth and multiplication of cells. Deficiency of zinc may contribute to arrested sexual maturation, growth retardation and hair loss, delayed wound healing and emotional disturbance (Iwaoka et al., 2011). Sodium (Na) is a mineral that human body must have in order to function properly. Sodium is vital to a number of routine body functions. Concentrations of sodium control the distribution of fluids in the body, maintains the osmotic equilibrium in cells, concern with the conduction of nervous impulses, muscle contractility and control heart muscle conduction (Rajurkar and Damame, 1997). Sodium also helps to transport other minerals and substances into, and out of, cells. Manganese (Mn) can help to assist the human body in metabolizing 
protein and carbohydrates (Fraga, 2005). Potassium (K) plays vital role in many physiological reactions in human body and its deficiency or excess can affect human health (Fraga, 2005).

For normal growth medicinal plants not only need nutrients, but also can selectively uptake and accumulate some elements which are good and may also be toxic for human health if these are not within the limits.

Lead $(\mathrm{Pb})$, cadmium $(\mathrm{Cd})$, mercury $(\mathrm{Hg})$, and arsenic $(\mathrm{As})$ have no beneficial effects in humans, and there is no known homeostasis mechanism for them (Draghici et al., 2010; Vieira et al., 2011). These elements are generally considered the most toxic to humans and animals, even at low concentrations (Jomova and Valko, 2010; Tokar et al., 2011). Chromium (Cr) is considered as human carcinogen in one form or another or in particular routes of exposure (NTP, 2002).

\section{Conclusion}

The results from this study showed that the flowers of Nyctanthes arbor-tristis L. contain several important phytochemicals and phytonutrients. The flowers have proven to be considered as a major source of potassium, calcium, magnesium, sodium, iron and zinc. The presence of necessary phytoconstituents, safe level of toxic elements and good source of minerals in the flowers of Nyctanthes arbor-tristis L. suggest and justify that, it is safe for consumption and also usable for preparations for herbal formulations, products and tonics.

\section{References}

Abidemi OO (2013), Phytochemicals and Spectrophotometric Determination of Metals in Various Medicinal Plants in Nigeria, International Journal of Engineering Science Invention 2(5): 51-54.

Adam J, Singer MD, Steve A and McClain MD (2002), The Effect of high potency tropical steroid on cutaneous healing of burns in pigs, Acad. Emerg. Med. 9(10): 1-6. DO: org/10.1197/aemj.9.10.977

Adinortey MB, Sarfo JK, Quayson ET, Weremfo A, Adinortey CA, Ekloh W and Ocran J (2012), Phytochemical Screening, Proximate and Mineral Composition of Launaea taraxacifolia Leaves, Research Journal of Medicinal Plant 6(2): 171-179.

Alan LQ and Miller ND (1996), Antioxidant. Flavonoids: Structure, function and chemical usage, Alt. Med. Rev. 1: 103-111.

Annan K, Dickson RA, Amponsah IK and Nooni IK (2013), The heavy metal contents of some selected medicinal plants from different geographical locations, Pharmacognosy Res. 5(2): 103-108.

Annan K, Kojo AI, Cindy A, Samuel AN and Tunkumgnen BM (2010), Profile of heavy metals in some medicinal plants from Ghana commonly used as components of herbal formulation, Pharmacognosy Res. 2(1): 41-44. DOI: $10.4103 / 0974-8490.60579$

Anuradha SN, Ken MFT, Jing HM, Yee TM and Arunkumar S (2017), Herbal review on nyctanthes arbortristis L., Rapports De Pharmacie 3(1): 319-329.

AOAC (1990), Standard Official Methods of Analysis of the Association of Analytical Chemists. $16^{\text {th }}$ Ed. (Arlington, USA).

Archana K, Hong X and Mary M (2011), Evaluation of mineral content of Chinese medicinal herbs used to improve kidney function with chemo metrics, Food Chem. 127: 1465-1471. DOI: org/10.1016/j.foodchem.2011.01.106

Bailey SJ, Fulford J, Vanhatalo A, Winyard PG, Blackwell JR, DiMenna FJ, Wilkerson DP, Benjamin N and Jones AM (2010), Dietary nitrate supplementation enhances muscle contractile efficiency during knee-extensor exercise in humans, J. Appl. Physiol. 109: 135-148. DOI: org/10.1152/japplphysiol.00046.2010

Bajai AM (2001), Effect of Natural extract of pineapple on disstibility, performance traits and nitrogen balance of broiler chicks, Aust. J. Basic Appl. Sci. 5(20): 10-30.

Balch JF and Balch PA (2000), Prescription for Nutritional Healing. (Avary, Penguin Putnam Inc, New York), pp 267-270.

Brody T (1994), Nutritional Biochemistry. (Academic Press, San Diego CA).

Cerenak I and Vink R (1999), Magnesium as a regulatory cation in direct and indirect traumatic brain injury. In: Magnesium in the environment and organisms. Proceedings of the first symposium on magnesium, 14 December, 1998, Belgrade, pp 10- 14.

Chong EW, Wong TY, Kreis AJ, Simpson JA and Guymer RH (2007), Dietary antioxidants and primary prevention of age related macular degeneration: systematic review and meta-analysis, $B M J$. 335- 755.

Detopoulou P, Panagiotakos DB, Antonopoulou S, Pitsavos C and Stefanadis C (2008), Dietary choline and betaine intakes in relation to concentrations of inflammatory markers in healthy adults: The ATTICA study, Am. $J$. Clin. Nutr. 87: 424-430. 
Dhar ML, Dhar MM, Dhawan BN and Ray C (1987), The chemistry and biological significance of saponins in food and feeding stuffs, Crit. Rev. Food Sci. Nutr. 26: 22-48.

Draghici C, Coman G, Jelescu C, Dima C and Chirila E (2010), Heavy metals determination in environmental and biological samples. In: Environmental Heavy Metal Pollution and Effects on Child Mental DevelopmentRisk Assessment and Prevention Strategies, NATO Advanced Research Workshop, Sofia, Bulgaria.

Duijvenboden WV and Matthijsen AJCM (1989), Integrated criteria document nitrate. RIVM Report No. 758473012. (National Institute for Public Health and the Environment, Bilthoven).

Ebun-Oluwa PO and Alade AS (2007), Nutritional potential of Belandiern Nettle spurge Jatropha cathatica seed, Pak. J. Nutr. 6: 345-348.

Edeoga HO, Okwu DE and Mbaebie BO (2005), Phytochemical Constituents of some Nigerian Medicinal Plants, Afr. J. Biotechnol. 4(7): 685-688.

Engvild KC (1986), Chlorine-containing natural compounds in higher plants, Photochemistry 25: 781-791.

FAO/WHO (2001), Food additives and contaminants. Codex Alimentarius Commission. Joint FAO/WHO Food Standards programme; ALINORM 01/12A, 1-289.

Fraga CG (2005), Review Relevance, essentiality and toxicity of trace elements in human health, Molecular Aspects of Medicine 26: 235-244. DOI: org/10.1016/ j.mam.2005.07.013

Ghani A (2003), Medicinal Plants of Bangladesh with Chemical Constituents and Uses. 2 ${ }^{\text {nd }} \mathrm{Ed}$. (Asiatic Society of Bangladesh, Dhaka-1000, Bangladesh), pp 497-505.

Harborne JB (1998), Phytochemical Methods. $3^{\text {rd }}$ Ed. (Chapman and Hall Co, New York), pp 1-302.

Hill AF (1952), Economic Botany, A textbook of useful plants and plant products. 2 ${ }^{\text {nd }}$ Ed. (McGarw-Hill Book Company Inc, New York).

ICAIR Life Systems, Inc (1987), Drinking water criteria document on nitrate/nitrite. (United States Environmental Protection Agency, Office of Drinking Water, Washington DC.)

Iwaoka WT, Kartika H, Shido J, Nakamoto ST and Li QX (2011), Nutrient and mineral composition of dried Mamaki leaves (Pipturus albidus) and infusions, J. Food Compos. Anal. 24: 44-48.
Jacob SJP and Shenbagaraman S (2011), Evaluation of antioxidant and antimicrobial activities of the selected green leafy vegetables, Int. J. Pharm. Tech. Res. 3(1): 148-152.

Jain PK and Pandey A (2016), The wonder of Ayurvedic medicine - Nyctanthes arbortristis, Int. Journal of Herbal Medicine 4(4): 09-17.

Jomova K and Valko M (2010), Advances in metal-induced oxidative stress and human disease, Toxicology 283: 65-87. DOI: org/10.1016/j.tox.2011.03.001

Kirkby EA (1974), Recycling of potassium in plants considered in relation to ion uptake and organic acid accumulation. In: Plant Analysis and Fertilizer Problems, Proceedings of the 7th Int. Colloquium, Hanover, Federal Republic of Germany, 557-568.

Kirk RS (1993), Analysis of Food. In: Encyclopedia of Food Science, Food Technology and Nutrition Macrae R, Robinson RK, Sadler MJ. ed. (Academic Press, New York), pp 183 - 188.

Ladipo MK, Doherty VF and Kanife UC (2011), Heavy metal analysis and phytochemical screening of two indigenous species (Zingiber officinale and Centrosema pubescens) from Nigeria, International Journal of Current Research 3(4): 095-099.

Lansley KE, Winyard PG, Fulford J, Vanhatalo A, Bailey SJ, Blackwell JR, DiMenna FJ, Gilchrist M, Benjamin N and Jones AM (2011), Dietary nitrate supplementation reduces the $\mathrm{O}_{2}$ cost of walking and running: $A$ placebo-controlled study, J. Appl. Physiol. 110: 591-600. DOI: org/10.1152/japplphysiol.01070.2010

Larsen FJ, Schiffer TA, Borniquel S, Sahlin K, Ekblom B, Lundberg JO and Weitzberg E (2011), Dietary inorganic nitrate improves mitochondrial efficiency in humans, Cell Metab. 13: 149-159. DOI: org/10. 1016/j.cmet.2011.01.004

Lorenz H (1976), Nitrate, ammonium and amino acids in bleeding sap of tomato plants in relation to the form and concentration of nitrogen in the medium, Plant Soil. 45: 169-176.

Lundberg JO, Weitzberg E and Gladwin MT (2008), The nitrate-nitrite-nitric oxide pathway in physiology and therapeutics, Nat. Rev. Drug Discov. 7: 156-167.

Malik RN, Hussain SZ and Nasir I (2010), Heavy metal contamination and accumulation in soil and wild species from industrial area of Islamabad, Pakistan, Pak. J. Bot. 42(1): 291-301. 
Mukherjee PK (2002), Quality Control of Herbal Drugs- an approach to evaluation of botanicals. $1^{\text {st }}$ Ed. Business Horizons, New Delhi.

NTP, National Toxicology Program (2002), $10^{\text {th }}$ Report on carcinogens. Department of Health and Human Services, Public Health Service, Washington DC, USA.

Osabor VN, Bassey FI and Umoh UU (2015), Phytochemical Screening and Quantitative Evaluation of Nutritional Values of Zingiber officinale (Ginger), American Chemical Science Journal 8(4): 1-6.

Pascaline J, Charles M and Lukhoba C (2011), Phytochemical constituents of some medicinal plants used by the Nandis of South Nandi district Kenya, Journal of Animal \& Plant Sciences 9(3): 1201- 1210.

Pourmorad F, Hosseininelir SJ and Shahabimajd N (2006), Antioxidant activity, phenol and flavonoid content of some selected Iraninan medicinal plants, Afr. J. Biotechnol. 5(11): 1142-1145.

Rahila T, Rukhsandra N and Zaidi A (1994), Phytochemical screening of medicinal plants belonging on Euphorbiaceae, Pak. Vet. J. 14: 160-162.

Rajurkar NS and Damame MM (1997), Elemental analysis of some Herbal plants used in the treatment of Cardiovascular Diseases by NAA and AAS, Journal of Radioanalytical and Nuclear Chemist 219(1): 77-80.

Rani C, Chawla S, Mangal M, Mangal AK, Kajla S and Dhawan AK (2012), Nyctanthes arbor-tristis L.. (Night Jasmine): A sacred ornamental plant with immense medicinal potentials, Indian Journal of Traditional Knowledge 11(3): 427-435.

Rao KP and Rains DW (1976), Nitrate absorption by barley. I. Kinetics and energetics, Plant Physiol. 57: 55-58. DOI: org/10.1104/pp.57.1.55

Raquel FE, Paul BS and Richard ME (2007), Bacterial lipid composition and antimicrobial efficacy of cationic steroid compounds (Ceragenins), Biochemica et Biophysica Acta 1768(10): 2500-2509.

Saracoglu S, Tuzen M and Soylak M (2009), Evaluation of trace element contents of dried apricot samples from Turkey, J. Hazard Mater. 156: 647-652. DOI.org/10.1016/j.jhazmat.2009.01.011

Shute KH (1964), The Biological of trace elements their role in nutrition. (JB Lippincot co, Philadelphia, USA).

Sofowara A (1993), Medicinal Plants and Traditional Medicine in Africa. (Spectrum Books Ltd, Ibadan, Nigeria), p 289.
Tokar EJ, Benbrahim-Tallaa L and Waalkes MP (2011), Metal ions in human cancer development, Met. Ions. Life Sci. 8: $375-401$.

Trease GE and Evans WC (1996), A textbook of Pharmacognosy, $14^{\text {th }}$ Ed., Bailliere Tindall Ltd, London.

Ugwu OPC, Nwodo OFC, Joshua PE, Bawa A, Ossai EC and Odo CE (2013), Phytochemical and Acute Toxicity Studies of Moringa oleifera Ethanol Leaf Extract, Int. J. Life Sc. Bt \& Pharm. Res. 2(2): 66-71.

Usunobun U, Okolie NP, Anyanwu OG, Adegbegi AJ and Egharevba ME (2015), Phytochemical screening and proximate composition of Annona muricata leaves, European Journal of Botany Plaint Science and Phytology 2(1): 18-28.

Vasantha K, Priyavardhini S, Tresina SP and Mohan VR (2012), Phytochemical analysis and antibacterial activity of Kedrostis foetidissima (Jacq), Bioscience Discovery 3(1): 6-16.

Vieira C, Morais S, Ramos S, Delerue-Matos C and Oliveira MBPP (2011), Mercury, cadmium, lead and arsenic levels in three pelagic fish species from the Atlantic Ocean: intra- and inter-specific variability and human health risks for consumption, Food Chem. Toxicol. 49(4): 923-932. DOI: org/10.1016/ j.fct.2010.12.016

Vlietinck AJ and Apers S (2001), Biological screening methods in the search for pharmacologically active natural products. In: Bioactive Compounds from Natural Sources: Isolation, Characterization, and Biological Properties. Ed. Tringali C Taylor \& Francis, New York.

WHO, World Health Organization (2005), National Policy on Traditional Medicine and Regulation of Herbal Medicines, Report of a Global Survey.

Wisegeek (2013), What are Plant Steroids, Retrieved from: www.wisegeek.com/what-are-plant-steroids.htm.

Yap CK, Fitri M, Mazyhar Y and Tan SG (2010), Effects of Metalcontaminated Soils on the accumulation of heavy metals in different parts of Centella asiatica: A Laboratory Study, Sains Malaysiana 39(3): 347-52.

Yukari I, Youichi F, Ikuko N and Itsuru Y (1995), Quantitative HPLC analysis of cardiac glycosides in Digitalis purpurea leaves, J. Nat. Prod. 58(60): 897-901. 